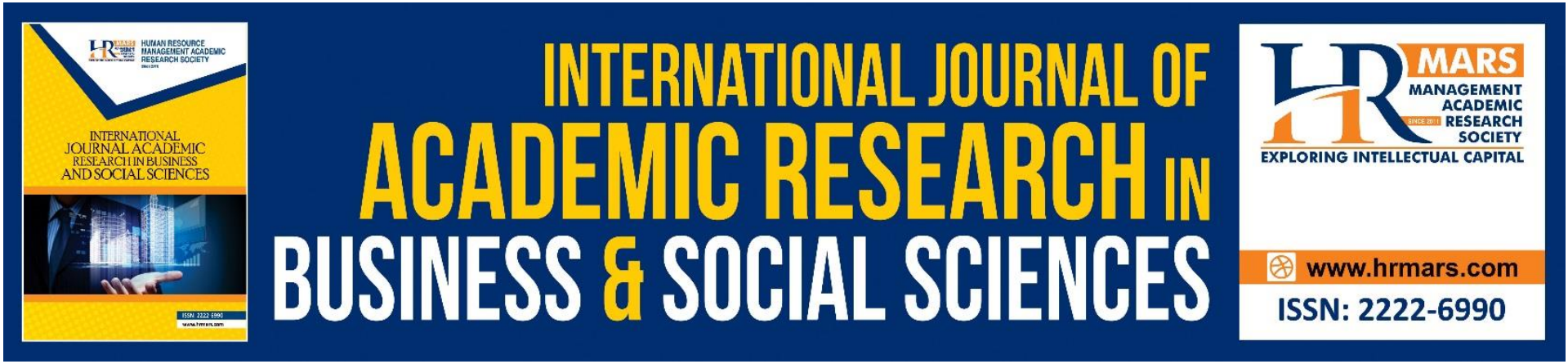

\title{
A Proposed Framework of School Inspection Outcomes: Understanding Effects of School Inspection and Potential Ways to Facilitate School Improvement
}

Nurul Jawahir Md Ali, Suhaida Abdul Kadir, Steven Eric Krauss, Ramli Basri \& Arnida Abdullah

To Link this Article: http://dx.doi.org/10.6007/IJARBSS/v11-i2/8451

DOI:10.6007/IJARBSS/v11-i2/8451

Received: 02 January 2021, Revised: 27 January 2021, Accepted: 10 February 2021

Published Online: 27 February 2021

In-Text Citation: (Ali et al., 2021)

To Cite this Article: Ali, N. J. M., Abdul Kadir, S., Krauss, S. E., Basri, R., \& Abdullah, A. (2021). A Proposed Framework of School Inspection Outcomes: Understanding Effects of School Inspection and Potential Ways to Facilitate School Improvement. International Journal of Academic Research in Business and Social Sciences, 11(2), 418-435.

Copyright: (c) 2021 The Author(s)

Published by Human Resource Management Academic Research Society (www.hrmars.com)

This article is published under the Creative Commons Attribution (CC BY 4.0) license. Anyone may reproduce, distribute, translate and create derivative works of this article (for both commercial and non-commercial purposes), subject to full attribution to the original publication and authors. The full terms of this license may be seen at: http://creativecommons.org/licences/by/4.0/legalcode

Vol. 11, No. 2, 2021, Pg. 418 - 435

Full Terms \& Conditions of access and use can be found at http://hrmars.com/index.php/pages/detail/publication-ethics 


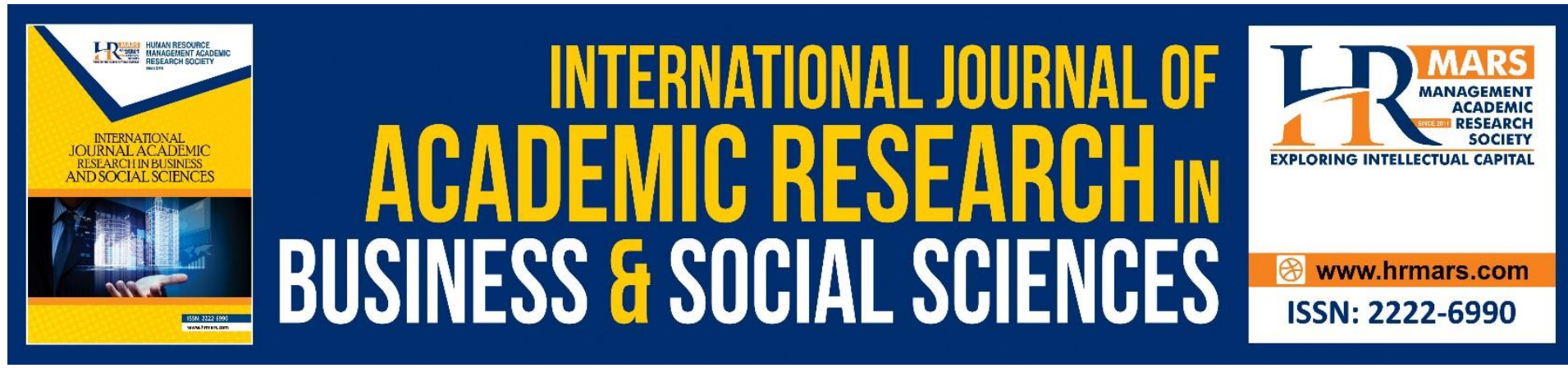

\title{
A Proposed Framework of School Inspection Outcomes: Understanding Effects of School Inspection and Potential Ways to Facilitate School Improvement
}

\author{
Nurul Jawahir Md Ali, Suhaida Abdul Kadir, Steven Eric Krauss, \\ Ramli Basri \& Arnida Abdullah \\ Faculty of Educational Studies, Universiti Putra Malaysia, 43400 UPM Serdang, Selangor, \\ Malaysia.
}

\begin{abstract}
This paper aims to develop a framework of school inspection outcomes by reviewing two models of school inspection effects towards school. The first framework by Ehren and Visscher (2006) describes school inspection as a process connected through features of school inspection, external impulses and support, school features, school reaction and its effects. The second model by Landwehr (2011) describes the benefits of school inspection as primary instrument for gaining knowledge, accountability, enforcing standard and school development and presents the school inspection desirable outcomes at its best. These two models then are combined together and a framework of school inspection outcome is proposed. This framework then may provide ground for future studies that wishes to study school inspection effects on school as well as to explore the potential ways to improve school inspection practices to optimize its contribution on school improvement.
\end{abstract}

Keywords: School Inspection, Effect, Side Effect, School Improvement.

\section{Introduction}

School inspection is a form of external evaluation conducted by officials that consists of group of inspectors, which has given the authority to visit school at its real-time operation to examine, assess and assist school towards legislation or standard compliance and ensuring the quality of education delivered (Eddy-Spicer et al., 2016; Gray \& Wilcox, 2006). It is a systematic, target-oriented, and criteria-based process conducted by an external authority that conducts data collection at school through school visits and provides feedback on school quality for the purpose in ensuring educational accountability, policy and school improvement (Hofer et al., 2020). The group of inspectors assigned with the task of inspecting school are the members under the school inspectorate, which is usually a national authority that's responsible in governing school quality.

School inspection has existed as a form of school supervision for a long time, since the end of $18^{\text {th }}$ century during the Napoleon regime in France (De Grauwe, 2007). This system 
then has also been implemented in other European countries, such as in Netherland known as The Dutch Inspectorate of Education) in 1801 (Ehren \& Honingh, 2011) and in Britain that was officially introduced in 1839 that known as Her Majesty's Inspectorate (HMI) (MacBeath, 2006). Although considered as a traditional and a bureaucratic form of supervision (Baxter, 2017), the practice remains until now as the common system of external evaluation to administer school as well as a means to ensure the quality assurance of educational service provided by school (Janssens \& van Amelsvoort, 2008; Whitby, 2010). Therefore, schools around the world especially Europe, in particular, has deemed school inspection as an essential instrument for external quality assurance and supervision (Hofer et al., 2020).

In an effort to conduct a study on school inspection effects in Malaysia, we have begun searching for theories and frameworks that explain the school inspection effects. Unfortunately, one that can be deemed as a well-established theory in providing explanation on school inspection effects are not be found. The use of theory in one's study is important in strengthening the research by providing ground and scaffolding for the study. It also gives the researcher lens to see a phenomenon in a specific paradigm and perspective. In the search for theoretical conception and understanding on the phenomenon, we found sound descriptions of school inspection effects at model and framework level that describes the school inspection effects and how school inspection can actually contribute towards school improvement. The specific models that we referred to are the 'Framework of School Inspection Effect' by Ehren and Visscher (2006) and 'Model of Effects and Effectiveness of School Inspection' by Landwehr (2011).

Both the frameworks by Ehren and Visscher (2006); Landwehr (2011) have provided great explanation on the effect and potential contribution of school inspection towards school development. Since both of these models described school inspection effects from different angles, ignoring and removing any one of these two in our research will be a waste. Ehren and Visscher (2006) asserts that in order to gain understanding and to expand the knowledge of school inspection effects, the development of a theoretical framework on the effects of school inspection is important to be discovered. Indeed, combining more theories compared to a single theory has a potential value in creating new perspectives and new research agendas (Cairney, 2013). Therefore, we selected these two models to form a framework in which both can complement the understanding of school inspection effects. This intention therefore leads to the aim of this paper, to present a proposed framework of school inspection outcomes.

This paper began by introducing the roles of school inspection followed by the discussion on its effects on school. Then, the two selected frameworks are presented and discussed. Finally, a framework from the combination of the two models are proposed. The development of this framework initially derived from our intention in finding theoretical ground to conduct a study on school inspection effects in our country, Malaysia. By presenting a framework, this article hopes to contribute in expanding the paradigm and understanding of school inspection effects. The development of such framework can potentially provide ground for future studies that wish to explore the school inspection effects that is still considered as lacking and inconclusive (Ehren \& Visscher, 2006; Hopkins et al., 2016; ). In addition, seeing the school inspection process through the lens of such framework can help the involving stakeholders including school inspectors, school administrators and teachers to improve their role and practice in going through the actual process and event of school inspection - their behaviour, perception and reaction towards school inspection. Such practices are important in determining the impact of school inspection as well as to prevent 
the occurrence of unintended effects that can potentially harm and undo the school inspection purpose and effort in safeguarding the quality of education.

\section{Roles of School Inspection}

Wilcox and Gray (1996) assert four primary functions of school inspection, which are: 1) 'inspection as evaluation, 2) 'inspection as auditing', 3) 'inspection as a disciplinary power', and 4) 'inspection as a form of social action'. 'Inspection as evaluation' placed concern in assessing and making judgment on school in ensuring that school is accountable for the action and education provided. The second role, 'inspection as auditing' is intended to ensure schools' adherence towards the educational policy, standards, and legislation established by the educational authority and government, in which the compliance towards such standards can guarantee a minimum level of educational quality has been practiced. Thirdly, the 'inspection as a disciplinary power' reflects the history of school inspection at the end of $18^{\text {th }}$ century in which institutions are governed and controlled by central government. Therefore, a control mechanism system like school inspection has been introduced to govern schools and to inculcate certain bureaucratic values into the schools (Glanz, 1991). The final role, which is 'inspection as a form of social action' can be described by understanding the interaction that occurred and involved in its process, that encompasses the relationship and communication between inspectors as the persons in charge that performed the inspection and the inspected key actors, which are teachers, head teacher or principals and sometimes students. These four functions suggested by Wilcox and Gray (1996) mostly reflect the traditional functions of school inspection as control mechanism to govern and to control school. School inspection however has extended its role in serving school that might contribute to school improvement.

From primarily focused to assess and making judgment on school, inspection practices has transformed in concentrating more to the advisory role in helping school specifically teachers and school managers on good practice (Hartley, 1972). Such advisory role indicates that inspectors has taken the role in assisting both teaching and the school managerial area of school. Through instructional supervision that took place during inspection, the teachers can learn to improve by the guidance provided by the inspector (Glanz, 1994). Such form of supervision can help school by empowering teachers to undertake their role and fulfilling the objective in lesson delivery (Haris et al., 2018). The interaction between inspector and head teacher may also develop the capacity for school to improve as head teacher that accompany inspectors during the inspection visit and classroom observation can learn from the comments given by the inspectors (Ehren et al., 2013). Therefore, this process can transfer the insight to the school stakeholders that can help school to improve their performance.

School inspection is an important and common practice in many countries that began in Europe and implemented at national level in other countries including Singapore and Malaysia. Given that the success and development of a nation mostly relied on its educational quality, guaranteeing and assuring the quality the education is the primary business for school inspection. Thus, school inspection is expected to perform and contribute to some positive effects on school, which still has been debated and will be discussed in the next section.

\section{The Effects of School Inspection}

"All around the world schools are inspected and the assumption is that this in a positive way contributes to the quality of schools and education systems" (Ehren \& Visscher, 2006, p. 53) 
Based on previous discussion on some of the roles of school inspection, it indicates that inspection is intended in ensuring school quality that can lead towards better practice and school improvement. However, that might not always be true. Evidence have shown diverse findings on school inspection effects towards school (Hopkins et al., 2016). Although there are some literature suggesting that school inspection can contribute towards school improvement (Altrichter \& Kemethofer, 2015; Ehren et al., 2013, 2015), some literature has associated school inspection with unintended effects including strategic activities by schools (de Wolf \& Janssens, 2007; Smith, 1995); disturbing effects on normal school life (Penninckx et al., 2015); emotional side effects (de Wolf \& Janssens, 2007; Penninckx et al., 2015), and narrowing of the curriculum and instructional strategies (Ehren et al., 2015; Jones et al., 2017).

The unintended effects of school inspection has been documented since 1990s, which mostly are negative and might potentially outweigh the intended positive effects of school inspection (Ehren et al., 2016). Smith (1995) suggested eight effects that occurred in forms of behaviours practiced by school that experienced high pressure during school inspection with the struggle and intention to improve their school appearance and performance. These effects are stated as below:

(1) Tunnel vision: emphasis and concentration over a specific indicator while might be neglecting other aspects or indicators at the same time due to the excessive focus on a particular performance aspect (de Wolf \& Janssens, 2007; Fitz-Gibbon, 1997)

(2) Sub-optimization: "narrow local objectives by managers, at the expense of the objectives of the organisation as a whole" (Smith, 1995, p. 286). Example: concentrating on potential pupils and neglecting the difficult pupils for the sake of achieving organisations objective as whole (Fitz-Gibbon, 1997)

(3) Myopia: "the pursuit of short term targets and solutions by administrator at the expense of legitimate long term objectives or policy" (Ehren \& Visscher, 2006, p. 63)

(4) Measure fixation: "an emphasis on measures of success rather than the underlying objective" (Smith, 1995, p. 290). Example: a teacher concentrates more on students that are likely to get grade ' $D$ ' to specifically address the indicator of students but failed to address the improvement of student achievement and teaching aspect as a whole (Fitz-Gibbon, 1997)

(5) Misrepresentation: "the deliberate manipulation of data so that reported behaviour differs from actual behaviour" (Smith, 1995, p. 292). Example: fraud and deception in providing the school data (de Wolf \& Janssens, 2007; Smith, 1995)

(6) Misinterpretation: the possible misinterpretation and confusion of the data due to the bounded rationality during inspection context that might not represent the actual school condition that may send wrong signal to inspector (Fitz-Gibbon, 1997; Smith, 1995)

(7) Gaming: "deliberate manipulation of behaviour to secure strategic advantage" (Smith, 1995, p. 298). It might involve the adjustment or distortion of data, figure and benchmark to produce desirable result (Fitz-Gibbon, 1997)

(8) Ossification: "organisational paralysis brought about by an excessively rigid system of performance" (Smith, 1995, p. 299). Example: fear of experimentation in teaching (Jones et al., 2017)

These effects are then further described and conceptualized by contemporary scholars including Ehren and Visscher (2006) and de Wolf and Janssens (2007). These unintended effects are not only negative but can also threaten to undo the intended positive effects of 
school inspection (Jones et al., 2017). Acknowledging these unintended effects is therefore important to ensure involving parties especially school inspectors to be aware of such harm and undesirable effects of school inspection.

Although there's so much highlight given to the negative and unintended outcomes of school inspection, the focus in providing description in how school inspection can help in contributing towards positive effects and improvement to school should also be addressed. By identifying and recognizing the potential effects of school inspection, the inspector and policymaker that involve in the school inspection process will be aware of any possible strategies and practices that may allow for the benefits and strengths of school inspection to outweigh and to undo these unintended effects. Therefore, this paper will then discusses the two frameworks of school inspection effects that can further describe the process towards school inspection effects including features of school inspection that may contribute towards school reaction and effects of school inspection and finally, a model that suggested potential ways for school inspection to facilitate school improvement.

\section{The Reviewed Frameworks}

Two models that described the effects of school inspection are chosen, which are 'Framework of School Inspection Effect' by Ehren and Visscher (2006) and 'Model of Effects and Effectiveness of School Inspection' by Landwehr (2011). The discussion on the model proposed by Landwehr however is referred to a secondary article that described his work by Gaertner, Wurster and Pant (2013) since the original work was written in German language.

\section{Framework of School Inspection Effect by Ehren and Visscher (2006)}

This framework by Ehren and Visscher (2006) described the school inspection effects as a process and continuum that consists of several aspects. The framework is constructed by reviewing literature that reported findings on school inspection intervention.

In the earlier stage of developing the model, they proposed the basic model of inspection effects that consist of three blocks that become the basis for the literature review in developing the framework. The basic model is presented in the Figure 1.

Figure 1. Basic framework of school inspection effects.

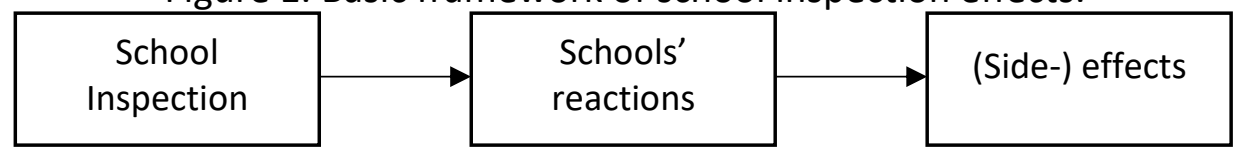

This basic model describes three primary aspects in school inspection effects which are the features and characteristics of the school inspection, schools' reactions to inspection and finally, the effects and side-effects of inspection. This model shows series of chain in the school inspection process itself that can be linked with the school reaction and the effects afterwards. The model is further elaborated by including the 'factors in and around the school' that may influence school reactions in having the school inspection. Since features around the school can stimulate and influence the school action, two aspects that influencing schools in reacting and responding to school inspections has been added, which are: a) school features, and, b) 'school external impulses and support'. The elaborated framework shown in Figure 2 presents factors in each of the aspects (in the block) that considered as relevant in discussing the school inspection effects. 
Figure 2. The elaborate framework of school inspection effects.

\begin{tabular}{|c|c|c|}
\hline \multirow{4}{*}{$\begin{array}{c} \\
\begin{array}{c}\text { Features of school } \\
\text { inspection }\end{array} \\
\end{array}$} & $\begin{array}{l}\text { External impulses and } \\
\text { support }\end{array}$ & \\
\hline & $\begin{array}{l}\text { - Pressure to improve } \\
\text { - Resources and } \\
\text { assistance }\end{array}$ & \\
\hline & School's reactions & (Side-)effects \\
\hline & Intended responses & Intended effects \\
\hline \multirow{4}{*}{$\begin{array}{l}\text { - Degree of } \\
\text { reciprocity and } \\
\text { trust in the } \\
\text { relationships } \\
\text { - Communication } \\
\text { style } \\
\text { - Nature of the } \\
\text { feedback } \\
\text { - Preventing } \\
\text { undesirable } \\
\text { behavior of } \\
\text { schools }\end{array}$} & $\begin{array}{l}\text { - Acceptance } \\
\text { - Genuine improvement } \\
\text { actions }\end{array}$ & \multirow{2}{*}{$\begin{array}{l}\text { - Improved student } \\
\text { achievement } \\
\text { - Pre-conditions for } \\
\text { improved student } \\
\text { achievement }\end{array}$} \\
\hline & Unintended responses & \\
\hline & \multirow{2}{*}{$\begin{array}{l}\text { - Rejection } \\
\text { - Tunnel vision } \\
\text { - Myopia } \\
\text { - Measure fixation } \\
\text { - Ossification } \\
\text { - Misrepresentation }\end{array}$} & Side effects \\
\hline & & $\begin{array}{l}\text { - Isomorphism } \\
\text { - Performance paradox } \\
\text { - Dependence } \\
\text { - Stigmatization of schools }\end{array}$ \\
\hline & School features & \\
\hline & $\begin{array}{l}\text { - Attitude towards } \\
\text { change } \\
\text { - Innovation capacity }\end{array}$ & \\
\hline
\end{tabular}

The framework encompasses of five primary aspects. The first three dimensions relates directly with school inspection which are, i) features of school inspection, ii) school's reactions, and iii) side-effects of inspection. The additional two dimensions however relates with internal and external school factors that might influence school reaction to inspection, which are iv) school features, and iv) external impulses and support. The description for the factor listed in the framework is listed in Table 1 below. 
Table 1. Description of factors in each of the aspects in the framework.

\begin{tabular}{|c|c|c|c|}
\hline $\begin{array}{l}\text { Features of school } \\
\text { inspection }\end{array}$ & Schools' reaction & (Side-)effects & $\begin{array}{l}\text { Factors in and } \\
\text { around the } \\
\text { school }\end{array}$ \\
\hline $\begin{array}{l}\text { - Degree of } \\
\text { reciprocity and trust } \\
\text { in the relationships: } \\
\text { Described } \\
\text { inspectors' } \\
\text { relationships with } \\
\text { schools that play } \\
\text { crucial role that may } \\
\text { 'encourage schools } \\
\text { to have an open } \\
\text { attitude about their } \\
\text { strengths and } \\
\text { weaknesses, and to } \\
\text { act upon } \\
\text { recommendations' } \\
\text { - Communication } \\
\text { style: described by } \\
\text { dimensions of } \\
\text { power (the extent } \\
\text { to which the } \\
\text { inspector gives } \\
\text { direction to the } \\
\text { interaction process) } \\
\text { and nearness } \\
\text { (relates to the } \\
\text { emotional distance } \\
\text { between the } \\
\text { inspector and other } \\
\text { participants in the } \\
\text { interaction process) } \\
\text { during interaction in } \\
\text { inspection context } \\
\text { - Nature of the } \\
\text { feedback: } \\
\text { provision the } \\
\text { feedback and the } \\
\text { feedback } \text { characteristics that } \\
\text { can influence school } \\
\text { response towards } \\
\text { the inspen }\end{array}$ & 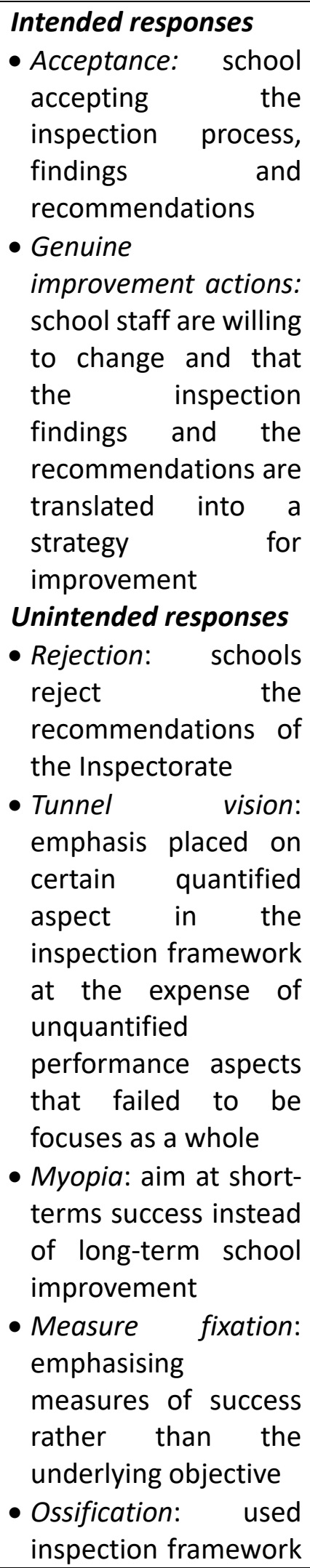 & $\begin{array}{l}\text { Intended effects } \\
\text { - Improved student } \\
\text { achievement: } \\
\text { school inspection in } \\
\text { improving student } \\
\text { achievement } \\
\text { - Pre-conditions for } \\
\text { improved student } \\
\text { achievement: } \\
\text { contributing factors } \\
\text { such as feedback to } \\
\text { and reinforcement } \\
\text { of students that can } \\
\text { provide conditions } \\
\text { for improvement } \\
\text { Side effects } \\
\text { - Isomorphism; } \\
\text { schools adjusting } \\
\text { their behaviour } \\
\text { accordingly to focus } \\
\text { on the performance } \\
\text { indicator } \\
\text { - Performance } \\
\text { paradox; refers to a } \\
\text { weak correlation } \\
\text { between } \\
\text { performance } \\
\text { indicators and real } \\
\text { performance } \\
\text { - Dependence: } \\
\text { schools: related to } \\
\text { inspection findings } \\
\text { and the negative } \\
\text { become dependent } \\
\text { on the Inspectorate } \\
\text { and become unable } \\
\text { decide } \\
\text { improvement } \\
\text { actions themselves } \\
\text { stigmation of } \\
\text { solion of }\end{array}$ & $\begin{array}{l}\text { School features } \\
\text { - Attitude } \\
\text { towards } \\
\text { change: staff's } \\
\text { attitude } \\
\text { towards } \\
\text { change and } \\
\text { recommendat } \\
\text { ion given by } \\
\text { Inspectorate } \\
\text { - Innovation } \\
\text { capacity: } \\
\text { schools' } \\
\text { capability to } \\
\text { implement } \\
\text { innovations } \\
\text { External } \\
\text { impulses and } \\
\text { support } \\
\text { - Pressure to } \\
\text { improve: } \\
\text { school } \\
\text { environment } \\
\text { like local } \\
\text { community } \\
\text { that can force } \\
\text { a school to } \\
\text { change } \\
\text { - Resources and } \\
\text { assistance: } \\
\text { external } \\
\text { resources and } \\
\text { help that can } \\
\text { stimulate } \\
\text { schools } \\
\text { change }\end{array}$ \\
\hline
\end{tabular}




\begin{tabular}{|l|l|l|l|}
\hline $\begin{array}{l}\text { Preventing } \\
\text { undesirable } \\
\text { behaviour of }\end{array}$ & $\begin{array}{l}\text { rigidly and refrain } \\
\text { from innovating } \\
\text { schools: the practice }\end{array}$ & $\begin{array}{l}\text { publicity resulting } \\
\text { from this }\end{array}$ & \\
manipulation of data & & \\
in school inspection & so that reported & & \\
that can be & action differs from the & & \\
organised to & actual ones & & \\
prevent negative & & & \\
side-effects & & & \\
\hline
\end{tabular}

This framework presented a detailed process and constructs that's related with school inspection effect. The explanation on the school internal and external factors however has not been described in-depth. As school features are related with other variable instead of school inspection and a detailed description on this matter has not been provided, the final framework will not include these factors as to only focuses on school inspection process. Therefore, only the aspects of 'features of school inspection', 'schools' reaction' and 'side effects' are included in constructing the framework.

It important to note that this framework has actually underwent some adjustment over time and has been revised by Ehren and colleagues in developing more elaborated framework in describing the causal mechanism of school inspection. Ehren et al. (2013) reported the revised version of this framework through the study on the impact of school inspections on improvement of schools in six European countries, including The Netherlands, England, Sweden, Ireland, Austria and Czech Republic. In her work in 2016 (Ehren \& Pietsch, 2016), the latest version of the framework was referred to as 'theory of action about the impact of school inspections'. As the revised version is rooted and derived from the European study, the model is much more complex and might not be related with the practice of school inspection in other context or country (example: the public reporting of school inspection that is not practiced in Malaysia). Therefore, the framework by Ehren and Visscher (2006) that is much more concise is chosen to be discussed and employed.

Gustafsson et al. (2015) studied on how school inspection impacts the improvement of school based on the revised model. Based on the data from principal's survey answer, the study reported that "inspection drives change indirectly, by encouraging certain developmental processes, rather than through more direct coercive methods" (Gustafsson et al., 2015, p. 47). This indirect change and developmental process is related with the next model by Landwehr that is going to be discussed. The upcoming model categorised four functions of school inspection in which each of the function described the developmental process of school inspection contribution on school improvement.

\section{Model of Effects and Effectiveness of School Inspection by Landwehr (2011)}

The second model to be discussed is the model of effects and effectiveness of school inspection by Landwehr (2011). While the framework of school inspection effects by Ehren and Visscher (2006) included both the positive and negative outcomes of school inspection, this model describes only the positive effects of school inspection. Ehren and Visscher has described the effects of inspection in both the schools' reactions and side effects of the inspection. Landwehr, however offered description on the effects based on the role and function of school inspection by describing how the school inspection take effect according to its functions. 
This model describes school inspection effects as a set of four functions whereby each of the functions reflected positive effects of inspection. School inspection is considered as an instrument in i) gaining knowledge, ii) 'accountability', iii) 'school development' (or also school improvement), and iv) 'enforcing standards'. Figure 3 presents the four functions of school inspection along with the relation and description between one function to another.

Figure 3. Model of effects and effectiveness of school inspection by Landwehr (2011).

\begin{tabular}{|c|c|c|}
\hline $\begin{array}{l}\text { School } \\
\text { inspection as an } \\
\text { instrument of } \\
\text { gaining }\end{array}$ & $\begin{array}{l}\text { Empirical data on school quality is the basis } \\
\text { of accountability }\end{array}$ & $\begin{array}{c}\text { School } \\
\text { inspection as an } \\
\text { instrument of }\end{array}$ \\
\hline & \multirow{2}{*}{$\begin{array}{lr}\text { Data collection on the } & \text { Accountability can } \\
\text { state of standards acts as } & \text { lead to an order of } \\
\text { a form of } & \text { development } \\
\text { communication and } & \text { measures }\end{array}$} & \\
\hline $\begin{array}{l}\text { New } \\
\text { knowledge } \\
\text { stimulates } \\
\text { actions of } \\
\text { school } \\
\text { development }\end{array}$ & & $\begin{array}{r}\text { Accountability } \\
\text { causes conscious } \\
\text { orientation } \\
\text { towards the } \\
\text { standards set }\end{array}$ \\
\hline $\begin{array}{l}\text { School } \\
\text { inspection as an } \\
\text { instrument for } \\
\text { school } \\
\text { development }\end{array}$ & $\begin{array}{l}\text { Kequesting standard compliance can } \\
\text { stimulate development processes }\end{array}$ & $\begin{array}{l}\text { School } \\
\text { inspection as an } \\
\text { instrument of } \\
\text { enforcing }\end{array}$ \\
\hline
\end{tabular}

Each of these four functions has positive effects based on its own function and can also contributes to other effects related with other functions. The description of the effects and contribution within and between the functions is provided in Table 2 . 
Table 2. Description of effects for four inspection functions.

\begin{tabular}{|c|c|c|c|}
\hline Gaining knowledge & Accountability & $\begin{array}{l}\text { Enforcing } \\
\text { standards }\end{array}$ & $\begin{array}{l}\text { School } \\
\text { development }\end{array}$ \\
\hline $\begin{array}{l}\text { To capture the current } \\
\text { picture of school quality } \\
\text { that school staff might } \\
\text { have less known or } \\
\text { identified. } \\
\text { Contribute } \\
\text { accountability by } \\
\text { proving data on } \\
\text { school quality school } \\
\text { Contribute to school } \\
\text { development by } \\
\text { providing knowledge } \\
\text { about } \\
\text { condition to the } \\
\text { school staffs } \\
\text { Contribute } \\
\text { standard } \\
\text { enforcement by } \\
\text { gaining info and } \\
\text { reinforcement action } \\
\text { based on the data of } \\
\text { standard practices at } \\
\text { school }\end{array}$ & $\begin{array}{l}\text { The function that } \\
\text { concerns about } \\
\text { the quality of } \\
\text { schools. } \\
>\text { Contribute to } \\
\text { school } \\
\text { development by } \\
\text { giving out order } \\
\text { for } \\
\text { development } \\
\text { measures } \\
\text { Contribute to } \\
\text { standard } \\
\text { enforcement by } \\
\text { promoting } \\
\text { consciousness } \\
\text { towards } \\
\text { practicing the } \\
\text { standard }\end{array}$ & $\begin{array}{l}\text { To ensure that } \\
\text { school practices } \\
\text { meet the criteria } \\
\text { and standards } \\
\text { that has been } \\
\text { prescribed } \\
>\text { Contribute to } \\
\text { school } \\
\text { development } \\
\text { as adherence } \\
\text { to standards } \\
\text { can encourage } \\
\text { the school } \\
\text { development } \\
\text { process }\end{array}$ & $\begin{array}{l}\text { Making way for } \\
\text { school } \\
\text { development } \\
\text { that can help } \\
\text { school to } \\
\text { improve } \\
\text { Contribute to } \\
\text { standard } \\
\text { enforcement } \\
\text { as } \\
\text { development } \\
\text { procedure will } \\
\text { enable the } \\
\text { execution and } \\
\text { compliance of } \\
\text { the given } \\
\text { standards }\end{array}$ \\
\hline
\end{tabular}

There is a limited discussion offered here on the research findings in relation to this piece of work as the original work as well as other literature citing this article are written in German language. Therefore, in discussing research findings related with this model, the literature by Gaertner et al. (2013) is chosen to be discussed. A longitudinal control-group study by Gaertner et al. (2013) has employed this model in examining how teachers and principals of inspected versus uninspected schools perceive school improvement at their schools. The findings that are in relation with Landwehr's model indicates that: (a) the inspection process described generates knowledge about the quality of schools; (b) this knowledge is, however, only rarely used for autonomous school improvement; (c) school authorities do use the newly generated knowledge. These findings indicate that school inspection may not have direct contribution to school improvement, but it were provided indirectly from their contribution to accountability. The findings suggested by this study, however, might be differ with study using different design or methodological approach.

This model is used to substantiate the previous model by Ehren and Visscher (2006). It has provided the description of potential effects of school inspection in positive view. The school inspection in this view may not only be employed for the purpose of traditional school accountability but rather, within a complex network of educational discourse (Brown et al., 2016). The understanding on the school inspection function and role can be helpful in minimizing the unwanted effects whereby school may realise the benefits that can be utilized through such functions. Each of these roles has its own corresponding effects and may lead 
to another benefit. Both of this model by Landwehr (2011) and Ehren and Visscher (2006) are combined and integrated in the next section.

\section{A Proposed Framework of School Inspection Outcome}

Although school supervision can generally describe school inspection, as a traditional and bureaucratic form of supervision; the theories and models used in describing supervision are more closely related with the instructional supervision, that associated with the pedagogy and the process of teaching and learning. School inspection as a different form of supervision should be seen and described differently. However, there isn't much theory in describing school inspection. Its implementation relied more on the framework established by the national authority that consists of standards in ensuring a good quality education. This framework is varied according to regions and countries. While local frameworks or standards might contrast across nations, the existence of empirical framework is important to describe some aspects of school inspection such as the functions, process, characteristics and effects.

As mentioned earlier regarding the effects of school inspection, it has been reported that studies on the school inspection effects on school shown mixed picture, that uncovers both positive and negative sides of school inspection effects (Hopkins et al., 2016). The emergence of inconclusive research evidences on this matter is might likely to be caused by the lack of theoretical models which account for the specific features of inspection approaches Husfeldt (2011, as cited in Altrichter \& Kemethofer, 2015). Although the practical differences in exercising school inspection according to local context might describe the multiple findings on this subject, the presence of a detail framework is important in providing detail description and explanation on school inspection phenomenon, especially on its process and effects on school. Therefore, the purpose of this paper is to propose a framework that can potentially contribute to the body of knowledge and in implementing research related with school inspection effects.

Both frameworks of school inspection effects by Ehren and Visscher (2006) and Landwehr (2011) presented before provides understanding of school inspection effects from different perspective. While the framework by Ehren and Visscher provides elaborate description with several variables and different factors in describing the inspection effects, the model by Landwehr offered comprehensive model on the potential effects of school inspection based on its four functions that lenses only on positive outcomes. These two models are merged together to form a framework that can be utilized in studying school inspection effects. For the first model, the author only chose the basic aspects of school inspection effects which are, features of school inspection, schools' reactions, and the effects and side-effects of inspection. The proposed framework is presented in Figure 4.

The proposed framework begins by addressing the 'perceived functions of school inspection and its effects and contribution on school' and the 'perceived features of school inspection'. This first construct, which is the 'perceived functions of school inspection' is derived from Landwehr's model of effects and effectiveness of school inspection. Is describes the process of school inspection based on its functions that might lead to school improvement. The 'perceived features of school inspection' is derived from Ehren and Visscher's model that describes the characteristics of the inspection process and the characteristics of the inspectors. As the school inspection process consists of activities and procedures in fulfilling its functions as well as the occurrence of interaction among school staffs with the inspectors, the participants or respondents that involve with the activity may 
possess certain mindset or perception towards the execution of the event that relates with both the 'perceived functions' and the 'the perceived features of school inspection'.

Both of these 'perceived elements' are placed together in further describing the reaction and effects of school inspection. Understanding the process of school inspection in relation to its functions (based on Landwehr's model): collecting information regarding school, ensuring school's accountability, enforcing education standards, and promoting school development, can provide knowledge and understanding on to what extent the function is fulfilled and its effects on school. The perception of school inspection features placed concern on how the inspection process and the inspector's characteristics will influence the teachers and principals' reaction and the effects on them a and their school.

Figure 4. The framework of school inspection effects.

\begin{tabular}{|c|c|c|}
\hline \multirow{2}{*}{$\begin{array}{l}\text { Perceived Functions of } \\
\text { School Inspection \& Its } \\
\text { Contribution on School }\end{array}$} & School's Reactions & Effects \& Side Effects \\
\hline & Intended responses & Intended effects \\
\hline $\begin{array}{l}\text { - Gaining knowledge } \\
\text { - Accountability } \\
\text { - Enforcing standards } \\
\text { - School development }\end{array}$ & $\begin{array}{l}\text { - Acceptance } \\
\text { - Genuine } \\
\text { improvement actions }\end{array}$ & $\begin{array}{l}\text { - Improved student } \\
\text { achievement } \\
\text { - Pre-conditions for }\end{array}$ \\
\hline $\begin{array}{l}\text { Perceived Features of } \\
\text { School Inspection }\end{array}$ & Unintended responses & $\begin{array}{l}\text { - Gaining knowledge on } \\
\text { school quality }\end{array}$ \\
\hline \multirow[b]{2}{*}{$\begin{array}{l}\text { - Degree of reciprocity } \\
\text { and trust in the } \\
\text { relationships } \\
\text { - Communication style } \\
\text { - Nature of the feedback } \\
\text { - Preventing undesirable } \\
\text { behavior of schools }\end{array}$} & \multirow[b]{2}{*}{$\begin{array}{l}\text { - Rejection } \\
\text { - Tunnel vision } \\
\text { - Myopia } \\
\text { - Measure fixation } \\
\text { - Ossification } \\
\text { - Misrepresentation }\end{array}$} & accountability \\
\hline & & $\begin{array}{l}\text { - Isomorphism } \\
\text { - Performance paradox }\end{array}$ \\
\hline
\end{tabular}

The framework above has included all the dimensions that exist in the original model of Landwehr and Ehren and Visscher. The dimension in this framework is then further categorized and a conceptual framework is proposed, as presented in Figure 5. There are three primary elements in discussing school inspection effects and effectiveness. The first element is perception towards school inspection that consists of functions of school inspection (Landwehr 2011) and features of school inspection (Ehren \& Visscher, 2006). The functions of school inspection derived from Landwehr's model can be used to study teachers' and principals' understanding on the school inspection purpose and process, as well as whether the function is reflected and materialized in the inspector's practice during school inspection. The second perception, 'features of school inspection' describes about characteristics of the school inspection that took place. The features of school inspection is important as correct strategies used by the school inspector can improve the acceptance and intended reaction of school representatives towards school inspection (Piezunka, 2019), and the acceptance of inspection feedback is important as it is assumed to be directly contributes to school improvement (Quintelier et al., 2020). 
The reaction to school inspection has been further categorized into three categories, namely positive response, rejection and misleading behaviour. The misleading behaviour consists of five affects stated in the model which are tunnel vision, myopia, measure fixation, ossification and misrepresentation. These reactions are linked with the school inspection outcomes that comprises of intended outcomes and side effects.

Figure 5. The conceptual framework of school inspection outcomes.

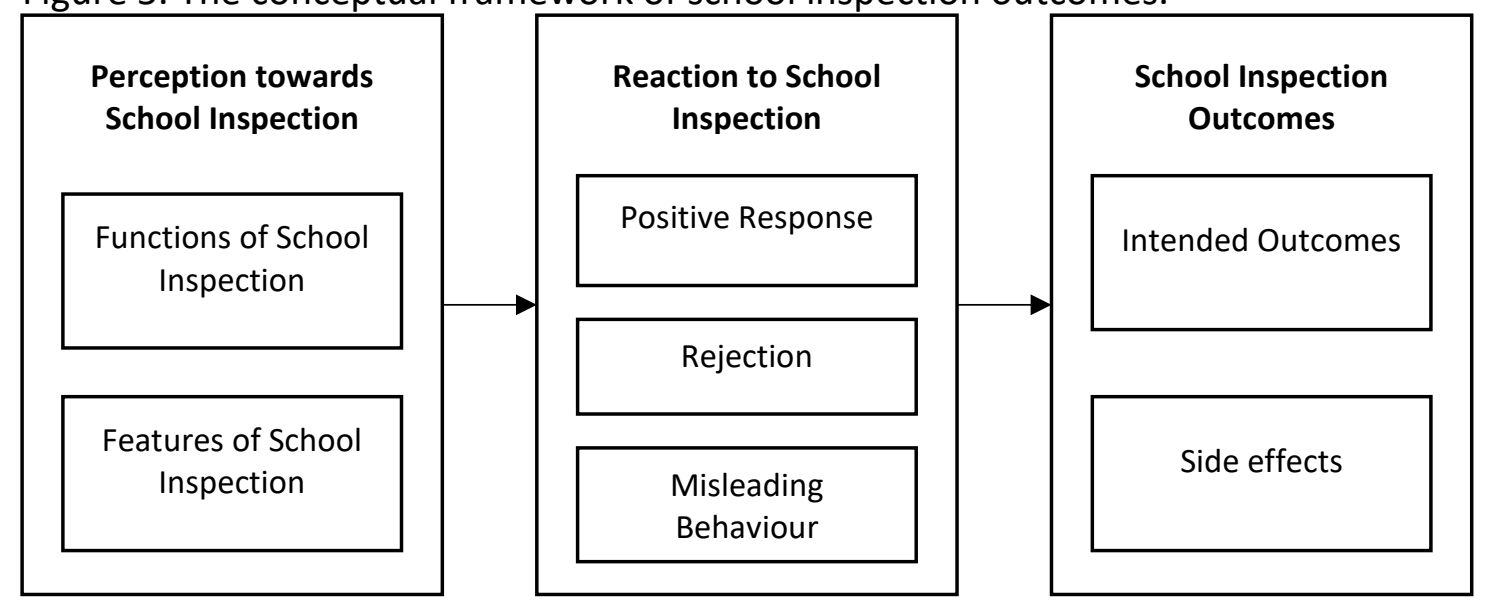

The merged framework as proposed above may have strength over a standalone model as it can widen the perspective and understanding of the topic studied. Therefore, the scope in describing the school inspection effects will be broader. The view and understanding on the functions of school inspection (as suggested by Landwehr) may enhance the current model of Ehren and Visscher as it can provide the perception and experience of the involved stakeholders, either teachers, principals and/or school inspectors on the actual function of school inspection. Such perception may be reflected through other questions such as - does it implemented the way it should be? does it meet its purpose? does the functions brings its desired effects? The inclusion of the Ehren and Visscher's model described the school inspection effects in detail. While the perceived functions described the perception on the inspection process based on its functions or objectives, the perceived school inspection features described the characteristics of the process in where both can possibly affect the school reaction that chained towards effects and side-effects of school inspection on school.

The combination of models may not only provide a clear framework in conducting a research but also enabling the area of discoveries in school inspection aspects that can strengthen the understanding and insights gained by researcher on how school inspection work based on its actual practices and how it affects teachers, principals, pupils, and schools. Such discovery might provide better understanding on the school inspection issue.

\section{Conclusion and the Way Forward for School Inspection Models Suggestion for Future Studies}

The framework proposed in this article can be utilized as guidance and scaffolding that can direct for future studies in making sense of the school inspection process and effects. The perception of school inspection effects can be studied by focusing on the key actors of the process which include teachers, school principals or head teachers, school managers and even students and parents. Future exploratory study on this topic might begin with qualitative research approach in gaining further and in-depth insight on the functions, features, reactions, effects and overall process of school inspection through interviews with key actors that experiencing school inspection. 
Since the models employed and presented above derived from European studies, researcher that wishes to embark in future research in this area should be sensitive on the school inspection context and standard used in their own countries. One of the factors that stated in the framework above which is 'stigmatization of schools' under the element of 'effects and side effects' is most likely impossible to occur in Malaysia's context since the result of school inspection are kept privately by School Inspectorate and the report are only provided to the respective school and to the Ministry of Education, which is also subjected to confidentiality under the provisions of subsection 120 (2) of the Education Act 1996 (Act 550). Past studies have also revealed that the occurrences of unintended responses are likely occurred in high-stake inspection systems (Brimblecombe et al., 1996; Ehren \& Visscher, 2006; Wagner, 2020). Therefore, such research should be context-sensitive to avoid the misrepresentation of the inspection system that implemented in the particular country.

Although primarily intended to help school to improve, the existence of undesirable effect of this system should not be taken lightly as it may outweigh the positive and desirable outcomes that it is intended to achieve. Insight into the effectiveness of school inspection has not much been provided although the study on the reform and shift of school inspection has been studied historically (Röbken et al., 2019). Therefore, more studies need to be conducted by using evaluative study design. In addition, the scarcity of school inspection effectiveness research and the lack of consideration in applying international and European knowledge and theoretical views in Asian studies, for example in China (Zheng, 2020) calls for further studies to consider its application in advancing the European derived model and framework to be measured and studied in Asian context in which the school environment and socio-economic conditions are different.

By reviewing two different models of school inspection effects, this paper has developed and proposed a framework of school inspection outcomes that can be later employed as ground for future exploratory study in this topic. Although frameworks and models for school inspection has been established according to national or local quality standard, employing an empirical model discusses here are useful to see the pattern of perception towards school inspection and how the effects of school inspection occurred. By combining two models of school inspection effects, it is hope to provide a more integrated view and perspective towards understanding the school inspection outcomes on school.

\section{References}

Altrichter, H., \& Kemethofer, D. (2015). Does accountability pressure through school inspections promote school improvement? School Effectiveness and School Improvement, 26(1), 32-56. https://doi.org/10.1080/09243453.2014.927369

Baxter, J. (2017). School Inspectors as Policy Implementers: Influences and Activities. In J. Baxter (Ed.), School Inspectors: Policy Implementers, Policy Shapers in National Policy Contexts. Springer.

Brimblecombe, N., Ormston, M., \& Shaw, M. (1996). Gender Differences in Teacher Response to School Inspection. Educational Studies, 22(1), 27-40.

https://doi.org/10.1080/0305569960220103

Brown, M., Mcnamara, G., O'Hara, J., O’Brien, S., \& Hara, J. O. (2016). Exploring the Changing Face of School Inspections. Eurasian Journal of Educational Research, 2016(66), 1-26. https://doi.org/10.14689/ejer.2016.66.1

Cairney, P. (2013). Standing on the Shoulders of Giants: How Do We Combine the Insights of Multiple Theories in Public Policy Studies? Policy Studies Journal, 41(1), 1-21. 
https://doi.org/10.1111/psj.12000

De Grauwe, A. (2007). Transforming school supervision into a tool for quality improvement. International Review of Education, 53(5-6), 709-714. https://doi.org/10.1007/s11159007-9057-9

de Wolf, I. F., \& Janssens, F. J. G. G. (2007). Effects and side effects of inspections and accountability in education: An overview of empirical studies. Oxford Review of Education, 33(3), 379-396. https://doi.org/10.1080/03054980701366207

Eddy-Spicer, D., Ehren, M. C. M. M., Bangpan, M., Khatwa, M., Perrone, F., Bangpan, M., EddySpicer, D., Ehren, M. C. M. M., Bangpan, M., Khatwa, M., \& Perrone, F. (2016). Under what conditions do inspection, monitoring and assessment improve system efficiency, service delivery and learning outcomes for the poorest and most marginalised? A realist synthesis of school accountability in low- and middle-income countries. EPPI-Centre, Social Science Research Unit, UCL Institute of Education, University College London.

Ehren, M. C. M., Altrichter, H., McNamara, G., \& O'Hara, J. (2013). Impact of school inspections on improvement of schools-describing assumptions on causal mechanisms in six European countries. Educational Assessment, Evaluation and Accountability, 25, 343. https://doi.org/10.1007/s11092-012-9156-4

Ehren, M. C. M., Gustafsson, J. E., Altrichter, H., Skedsmo, G., Kemethofer, D., Huber, S. G., Gustafsson, J. E., Altrichter, H., Skedsmo, G., \& Kemethofer, D. (2015). Comparing effects and side effects of different school inspection systems across Europe. Comparative Education, 51(3), 375-400. https://doi.org/10.1080/03050068.2015.1045769

Ehren, M. C. M., \& Honingh, M. E. (2011). Risk-based school inspections in the Netherlands: A critical reflection on intended effects and causal mechanisms. Studies in Educational Evaluation, 37(4), 239-248. https://doi.org/10.1016/j.stueduc.2012.02.001

Ehren, M. C. M., Jones, K., \& Perryman, J. (2016). Side Effects of School Inspection; Motivations and Contexts for Strategic Responses. In M. C. M. Ehren (Ed.), Methods and Modalities of Effective School Inspections. Springer.

Ehren, M. C. M., \& Pietsch, M. (2016). Validation of Inspection Frameworks and Methods. In M. C. M. Ehren (Ed.), Methods and Modalities of Effective School Inspections. Springer.

Ehren, M. C. M., \& Visscher, A. J. (2006). Towards A Theory On Impact of School Inspection. British Journal of Educational Studies, 54(1), 51-72.

Fitz-Gibbon, C. (1997). The value added national project: Final report - Feasibility studies for a national system of value added indicators.

Gaertner, H., Wurster, S., \& Pant, H. A. (2013). The effect of school inspections on school improvement. School Effectiveness and School Improvement, 25(4), 489-508. https://doi.org/10.1080/09243453.2013.811089

Glanz, J. (1991). Bureaucracy and Professionalism: The Evolution of Public School Supervision. Associated University Presses.

Glanz, J. (1994). History of Educational Supervision: Proposals and Prospects. Council of Professors of Instructional Supervision.

Gray, J., \& Wilcox, B. (2006). In the aftermath of inspection: the nature and fate of inspection report recommendations. Research Papers in Education, 10(1), 1-18. https://doi.org/10.1080/0267152950100102

Gustafsson, J. E., Ehren, M. C. M., Conyngham, G., McNamara, G., Altrichter, H., \& O'Hara, J. (2015). From inspection to quality: Ways in which school inspection influences change in schools. Studies in Educational Evaluation, 47, 47-57.

https://doi.org/10.1016/j.stueduc.2015.07.002 
Haris, I., Naway, F. A., Pulukadang, W. T., Takeshita, H., \& Ancho, I. V. (2018). School supervision practices in the indonesian education system; perspectives and challenges. Journal of Social Studies Education Research, 9(2), 366-387. https://doi.org/10.17499/jsser.17724

Hartley, O. A. (1972). Inspectorates in British Central Government. Public Administration, 50(4), 447-466. https://doi.org/10.1111/j.1467-9299.1972.tb00117.x

Hofer, S. I., Holzberger, D., \& Reiss, K. (2020). Evaluating school inspection effectiveness: A systematic research synthesis on 30 years of international research. Studies in Educational Evaluation, 65(6), 100864. https://doi.org/10.1016/j.stueduc.2020.100864

Hopkins, E., Hendry, H., Garrod, F., McClare, S., Pettit, D., Smith, L., Burrell, H., Temple, J., Hendry, H., Garrod, F., McClare, S., Pettit, D., Smith, L., Burrell, H., \& Temple, J. (2016). Teachers' views of the impact of school evaluation and external inspection processes. Improving Schools, 19(1), 52-61. https://doi.org/10.1177/1365480215627894

Janssens, F. J. G., \& van Amelsvoort, G. H. W. C. H. (2008). School self-evaluations and school inspections in Europe: An exploratory study. Studies in Educational Evaluation, 34(1), 1523. https://doi.org/10.1016/j.stueduc.2008.01.002

Jones, K. L., Tymms, P., Kemethofer, D., O’Hara, J., McNamara, G., Huber, S., Myrberg, E., Skedsmo, G., \& Greger, D. (2017). The unintended consequences of school inspection: the prevalence of inspection side-effects in Austria, the Czech Republic, England, Ireland, the Netherlands, Sweden, and Switzerland. Oxford Review of Education, 43(6), 805-822. https://doi.org/10.1080/03054985.2017.1352499

Landwehr, N. (2011). Thesen zur Wirkung und Wirksamkeit der externen Schulevaluation [Theses on the impact and effectiveness of the external evaluation of schools]. In C. Quesel, V. Husfeldt, N. Landwehr, \& P. Steiner (Eds.), Wirkungen und Wirksamkeit der Externen Schulevaluation [Effects and Effectiveness of External School Evaluation] (pp. 35-69). Hep der Bildungsverlag.

MacBeath, J. (2006). School inspection and self-evaluation: Working with the new relationship. In School Inspection and Self-Evaluation: Working with the New Relationship. Routledge. https://doi.org/10.4324/9780203967102

Penninckx, M., Vanhoof, J., De Maeyer, S., Van Petegem, P., Maeyer, S. De, \& Petegem, P. Van. (2015). Explaining effects and side effects of school inspections: a path analysis. School Effectiveness and School Improvement, 27(3), 333-347. https://doi.org/10.1080/09243453.2015.1085421

Piezunka, A. (2019). Struggle for acceptance - Maintaining external school evaluation as an institution in Germany. Historical Social Research, 44(2), 270-287.

https://doi.org/10.12759/hsr.44.2019.2.270-287

Quintelier, A., De Maeyer, S., \& Vanhoof, J. (2020). Determinants of teachers' feedback acceptance during a school inspection visit. School Effectiveness and School Improvement, 31(4), 529-547. https://doi.org/10.1080/09243453.2020.1750432

Röbken, H., Schütz, M., \& Lehmkuhl, P. (2019). From reform to reform: how school reforms are motivated and interrupted - the case of 'school inspections' in Germany. Journal of Educational Administration and History, 1-14.

https://doi.org/10.1080/00220620.2019.1585336

Smith, P. (1995). On the unintended consequences of publishing performance data in the public sector. International Journal of Public Administration, 18(2\&3), 277-310. https://doi.org/10.1080/01900699508525011

Wagner, I. (2020). Effectiveness and perceived usefulness of follow-up classroom 
observations after school inspections in Northern Germany. Studies in Educational Evaluation, 67(June), 100913. https://doi.org/10.1016/j.stueduc.2020.100913

Whitby, K. (2010). School Inspection: recent experiences in high performing education systems. Centre for British Teachers (CfBT) Education Trust.

Wilcox, B., \& Gray, J. (1996). Inspecting Schools: Holding Schools to Account and Helping Schools To Improve. Open University Press.

Zheng, H. (2020). Stakeholder perceptions on the role of school inspection standards in demonstrating education quality in China. Quality Assurance in Education, 28(2), 105121. https://doi.org/10.1108/QAE-09-2019-0093 